\title{
Analysis of bovine pulp tissue dissolution ability by photodynamic therapy: an in vitro study
}

\author{
Análise da capacidade de dissolução de tecido pulpar bovino \\ através da terapia fotodinâmica: estudo in vitro
}

\begin{abstract}
Purpose: To evaluate the bovine pulp tissue dissolution ability of photodynamic therapy.

Methods: Twenty pieces of bovine pulp tissue were weighed and divided randomly into four groups $(n=5)$, according to the cleaning protocol: $G 1$ - distilled water (negative control), G2 - sodium hypochlorite 1\% (positive control), G3 - photodynamic therapy, G4 - sodium hypochlorite $1 \%+$ photodynamic therapy. The observation of the events of dissolution was performed by two observers blinded in relation to the test using $2 x$ magnification, recording time in minutes until complete tissue dissolution. The total observation time was 2 hours. The dissolution rate was calculated dividing the weight of the fragment pulp $(\mathrm{mg})$ by the time of dissolution ( $\mathrm{mg} / \mathrm{min})$.

Results: Only group $2(\mathrm{NaOCl})$ was able to promote complete dissolution of pulp tissue. In the other groups there was no occurrence of complete dissolution of the samples. The mean dissolution time for samples from group $2(\mathrm{NaOCl})$ was $1.26 \mathrm{mg} / \mathrm{min}$.

Conclusion: Only the sodium hypochlorite was able to dissolve the fragments of bovine pulp tissue and photodynamic therapy does not show ability to dissolve tissue.
\end{abstract}

Key words: Pulp dissolution; sodium hypochlorite; photodynamic therapy

\section{Resumo}

Objetivo: Avaliar a capacidade de dissolução de tecido pulpar bovino com o uso da terapia fotodinâmica.

Metodologia: Vinte fragmentos de polpas bovinas foram pesados e distribuídos randomicamente em quatro grupos $(n=5)$ de acordo com os seguintes protocolos de limpeza: $\mathrm{G} 1$ - água destilada (controle negativo), G2 - hipoclorito de sódio 1\% (controle positivo), G3 - terapia fotodinâmica, G4 - hipoclorito de sódio 1\% + terapia fotodinâmica. A observação dos eventos de dissolução foi realizada por dois observadores, cegados quanto aos grupos experimentais, com lupa de $2 x$ de aumento, que registravam o tempo em minutos até a completa dissolução de tecido. O tempo total de observação foi de 2 horas. $O$ cálculo da taxa de dissolução foi feito dividindo o peso do fragmento pelo tempo de dissolução $(\mathrm{mg} / \mathrm{min})$.

Resultados: Somente o grupo $2(\mathrm{NaOCl} 1 \%)$ foi capaz de promover dissolução completa do tecido pulpar, tendo como média de dissolução 1,26 mg/min.

Conclusão: Apenas o hipoclorito de sódio foi capaz de dissolver os fragmentos de tecido pulpar bovino e a terapia fotodinâmica não mostrou capacidade de dissolução tecidual.

Palavras-chave: Dissolução pulpar; hipoclorito de sódio; terapia fotodinâmica

\author{
Liviu Steier a \\ Giampiero Rossi-Fedele ${ }^{a, b}$ \\ Monique Acauan b \\ Priscila Bianchini b \\ Matheus Albino Souza b \\ José Antônio Poli de Figueiredo b \\ - Warwick Dentistry, University of Warwick, Coventry, \\ United Kingdom \\ ${ }^{b}$ School of Dentistry, Pontifical Catholic University \\ of Rio Grande do Sul, Porto Alegre, RS, Brazil
}

\author{
Correspondence: \\ José Antonio Poli de Figueiredo \\ Post-Graduate Program in Dentistry - PUCRS \\ Av. Ipiranga 6681 Prédio 6 sala 507 \\ Porto Alegre, RS - Brazi \\ 90619-900 \\ E-mail: jose.figueiredo@pucrs.br
}

Aceived: January 10, 2011

Conflict of Interest Statement: The authors state that there are no financial and personal conflicts of interest that could have inappropriately influenced their work.

Copyright: (C) 2011 Steier et al.; licensee EDIPUCRS. This is an Open Access article distributed under the terms of the Creative Commons AttributionNoncommercial-No Derivative Works 3.0 Unported License. 


\section{Introduction}

The persistence of residual pulp tissue, infected dentin or bacteria inside the root canals may be responsible for the failure of endodontic treatment (1). Irrigating agents must present capacity of dissolving pulp remnants (2), since the removal of pulp tissue is inadequate with mechanical preparation alone, due to the complexities of the anatomical root canal system (3). Moreover, it is suggested that postoperative pain is more prevalent in cases of vital pulp than in cases of non-vital pulp (4) and the remaining pulp can cause postoperative pain (5).

Several studies have been conducted in search of an irrigant to provide four major properties: antimicrobial activity, non-toxicity to periapical tissues, solubility in water and ability to dissolve organic matter (6).

Sodium hypochlorite $(\mathrm{NaOCl})$ is considered the main irrigating substance in endodontics because of its broad antimicrobial spectrum, its ability to prevent the formation and dissolving the organic part of the smear layer, and its ability to dissolve organic tissue remnants (2). However, it has been shown a cytotoxic effect on vital tissues, causing severe inflammatory reactions to the periapex, with the concentration of $5.25 \%$ producing more toxic and caustic solutions than 0.5 and $1 \%$ (7). Moreover, low concentrations of sodium hypochlorite have reduced the ability to dissolve tissue (8), although this can be improved by increasing the temperature $(4,5)$.

Photodynamic therapy (PDT) or photoactivated disinfection uses light of a specific wavelength to activate a non-toxic photoactive dye, known as the photosensitizer in the presence of oxygen (9). The energy transferred from the activated photosensitizer to available oxygen results in the formation of highly reactive oxygen species, which may eliminate microorganisms by damaging their essential cellular molecules, including proteins, nucleic acids and lipid membranes $(10)$. In vitro $(11,12)$ and in vivo studies $(13,14)$ using photodynamic therapy have shown that this resource has the potential to maximize the disinfection of root canals.

However, there are no studies reporting the capability of photodynamic therapy in the dissolution of organic tissue. The aim of this study was to evaluate the ability of the dissolution of bovine pulp tissue through the action of photodynamic therapy.

\section{Methods}

The study was approved by the Ethics Committee of the Pontifical Catholic University of Rio Grande do Sul, Porto Alegre, RS, Brazil.

\section{Tissue preparation}

Ten bovine incisors were extracted, immersed in distilled water and stored at a temperature of $-20^{\circ} \mathrm{C}$ until required. The teeth were thawed at room temperature and two longitudinal grooves were prepared in buccal and lingual surfaces using a diamond disc (KG Sorensen, Barueri, Brazil), running from the crown portion to the apex. The teeth were split in half. The pulp tissue was removed and washed with distilled water. Each pulp sample was divided into two pieces of similar volume, resulting in 20 pieces.

\section{Preparation of solutions}

A solution of $1 \%$ sodium hypochlorite was prepared at the Endodontic Laboratory, School of Dentistry, Pontifical Catholic University of Rio Grande do Sul, from the solution of $2 \%$ sodium hypochlorite (Plus Virex - Johnson Diversey, Sturtevant, USA) diluted in distilled water in the proportion 1:1. A viscous solution of tolonium chloride was provided by the manufacturer of the photodynamic therapy device (PAD Plus, Denfotex Light Systems Ltd., Inverkeithing, Scotland).

\section{Dissolution process}

The pulp tissue fragments were weighed on a high precision balance (Sartorius BP61S, Göttingen, Germany), placed in transparent plastic pots and were divided randomly into four groups $(\mathrm{n}=5)$ according to initial weight:

- Group 1 - immersion in $1.5 \mathrm{~mL}$ of distilled water (negative control)

- Group 2 -immersion in $1.5 \mathrm{~mL}$ of $1 \%$ sodium hypochlorite (positive control)

- Group 3 - immersion in $1.5 \mathrm{~mL}$ of tolonium chloride, introduction of the tip of the PAD Plus (Denfotex Light Systems Ltd., Inverkeithing, Scotland) and activation of low power laser during a period of $120 \mathrm{~s}$ on the power of $120 \mathrm{~mW}$

- Group 4-immersion in $1.5 \mathrm{~mL}$ of $1 \%$ sodium hypochlorite for a period of $40 \mathrm{~min}$, immersion in $1.5 \mathrm{~mL}$ of distilled water, removal of the pulp fragment and immersion again in $1.5 \mathrm{~mL}$ of tolonium chloride, introduction of the tip of the PAD Plus (Denfotex Light Systems Ltd., Inverkeithing, Scotland) and activation of low power laser during a period of $120 \mathrm{~s}$ on the power of $120 \mathrm{~mW}$. The observation of the events of dissolution was performed by two observers blinded in relation to the test using $2 \mathrm{x}$ magnification, recording in minutes the time until complete tissue dissolution occurred. The total observation time was 2 hours. The time required for dissolution was recorded in minutes ( $\mathrm{min}$ ) and the dissolution rate was calculated by dividing the weight of the fragment pulp (mg) by the time of dissolution ( $\mathrm{mg} / \mathrm{min}$ ).

Results were presented in a table with average weights and dissolution times. Since only one experimental group showed total dissolution, no further statistical analysis was needed.

\section{Results}

The weight and time of dissolution of each pulp fragment are shown in Table 1 . Only group $2(\mathrm{NaOCl})$ was able to promote complete dissolution of pulp tissue. In the other groups there was no occurrence of complete dissolution of the samples. 
Table 1. Weight and time dissolution of dissolution of each pulp tissue sample.

\begin{tabular}{ccccccccccc}
\hline \multirow{2}{*}{ Group } & \multicolumn{2}{c}{ Sample 1 } & \multicolumn{2}{c}{ Sample 2 } & \multicolumn{2}{c}{ Sample 3 } & \multicolumn{2}{c}{ Sample 4 } & \multicolumn{2}{c}{ Sample 5 } \\
\cline { 2 - 10 } & $\begin{array}{c}\text { Weight } \\
(\mathbf{m g})\end{array}$ & $\begin{array}{c}\text { Time } \\
(\mathbf{m i n})\end{array}$ & $\begin{array}{c}\text { Weight } \\
(\mathbf{m g})\end{array}$ & $\begin{array}{c}\text { Time } \\
(\mathbf{m i n})\end{array}$ & $\begin{array}{c}\text { Weight } \\
(\mathbf{m g})\end{array}$ & $\begin{array}{c}\text { Time } \\
(\mathbf{m i n})\end{array}$ & $\begin{array}{c}\text { Weight } \\
(\mathbf{m g})\end{array}$ & $\begin{array}{c}\text { Time } \\
(\mathbf{m i n})\end{array}$ & $\begin{array}{c}\text { Weight } \\
(\mathbf{m g})\end{array}$ & $\begin{array}{c}\text { Time } \\
(\mathbf{m i n})\end{array}$ \\
\hline 1 & 99.7 & nildiss & 138.7 & nildiss & 71.7 & Nildiss & 69.7 & nildiss & 83.0 & nildiss \\
2 & 67.8 & 55 & 140.2 & 90 & 83.2 & 75 & 102.1 & 85 & 79.3 & 70 \\
3 & 66.8 & nildiss & 109.4 & nildiss & 108.2 & Nildiss & 72.8 & nildiss & 102.2 & nildiss \\
4 & 123.3 & nildiss & 145.7 & nildiss & 52.5 & Nildiss & 49.5 & nildiss & 52.7 & nildiss \\
\hline
\end{tabular}

The dissolution rate was calculated on the weight of the fragment of pulp tissue ( $\mathrm{mg}$ ) divided by the dissolution time (min), obtaining a value in $\mathrm{mg} / \mathrm{min}$. The mean dissolution time for samples from group $2(\mathrm{NaOCl})$ was $1.26 \mathrm{mg} / \mathrm{min}$.

\section{Discussion}

Previous studies have demonstrated the importance of the ability of an endodontic solvent and emphasized that the elimination of pulp tissue of the root canal was primordial to the success of endodontic treatment $(15,16)$. The bovine pulp tissue was used in our study because it is compared to human pulp tissue despite some minor differences (17). Moreover, previous studies have used the bovine pulp tissue to assess the capability of dissolving various endodontic irrigants $(18,19)$.

As a larger volume of sodium hypochlorite and contact surface leads to a greater ability to dissolve $(1,3)$ it can be speculated that the pots used in this experiment may have reduced the time of dissolution compared with the normal clinical conditions (in vivo), as it is most likely to occur according to previously reported in vitro investigations $(4,18,19)$.

The tissue dissolution is dependent on three factors: frequency of agitation, amount of organic matter in relation to the amount of irrigating and surface area of contact (1). The present study was standardized by using the same volume of irrigant and dye for the samples of the respective groups, besides the fact that all samples of bovine pulp tissue fragments showed similar mean weights $(90 \mathrm{mg})$.

The results were calculated in dissolution rates and not only time of dissolution, to compensate any variations in the weights of the fragments. The results of this study appear to be in line with previous investigations where only sodium hypochlorite showed ability to dissolve tissue $(18,20)$, although in a previous study the average speed of tissue dissolution to sodium hypochlorite was lower (18). This can be explained by differences in the volume of irrigant in contact with the pulp fragment, specifically the size and weight of the fragments, the concentration of sodium hypochlorite solutions, and perhaps a difference in temperature of the solutions.

Photodynamic therapy is a new antimicrobial strategy that involves the use of low-intensity laser, which operates through photosensitizing agents (21). The low-intensity laser, beyond been considered harmless to human tissue, has anti-inflammatory and analgesic effects. Its basic mechanism of the operation is based on biostimulation that occurs at the molecular level. The laser penetrates through the tissues and faces a photosensitizer in mitochondria of cells (22).

Disinfection by photo-activation method proves effective against endodontic bacteria, and has proved less toxic and faster than sodium hypochlorite (23). Furthermore, the infiltration of dentin tubules by sensitizers was evaluated microscopically, indicating the effectiveness of this therapy within the tubules (11). There are still records that indicate oral bacteria as susceptible to photodynamic therapy (12).

However, there are no previous studies that elucidate the capacity of tissue dissolution of photodynamic therapy. The results of this study show that photodynamic therapy has not got potential to dissolve the fragments of bovine pulp tissue in the tested groups, both when used alone, with the dye in contact with the pulp fragment and light activation, and when used in combination with sodium hypochlorite, where after immersion in $1 \%$ sodium hypochlorite the fragment was placed in contact with the dye and activated through photodynamic therapy.

The idea was that photodynamic therapy could exert an ability to dissolve in a previously unstructured tissue by initial action provided by previous immersion in sodium hypochlorite. However, this could not be observed, since the dissolution process was interrupted from the laser action, without such a development.

\section{Conclusion}

In conclusion, only the sodium hypochlorite showed ability to dissolve the fragments of bovine pulp tissue and photodynamic therapy does not aid to provide further dissolution. 
4. Abou-Rass M, Oglesby SW. The effects of temperature, concentration and tissue type on the solvent ability of sodium hypochlorite. J Endod 1981;7:376-7.

5. Cunningham WT, Balekjian BA. Effect of temperature on collagen-dissolving ability of sodium hypochlorite irrigant. Oral Surg Oral Med Oral Pathol 1980;49:175-7.

6. Kuruvilla JR, Kamath MP. Antimicrobial activity of $2.5 \%$ sodium hypochlorite and $0.2 \%$ chlorhexidine gluconate separately and combined as endodontic irrigants. J Endod 1998;24:472-6.

7. Pashley EL, Birdsong NL, Bowman K, Pashley DH. Cytotoxic effect of $\mathrm{NaOCl}$ on vital tissue. J Endod 1985; 1 1:525-8.

8. Hand RE, Smith ML, Harrison JW. Analysis of the effect of dilution on the necrotic tissue dissolution property of sodium hypochlorite. J Endod 1978;4:60-4.

9. Souza LC, Brito PRR, Oliveira JCM, Alves FRF, Moreira EJL, Sampaio-Filho HR et al. Photodynamic therapy with two different photosensitizers as a supplement to instrumentation/ irrigation procedures in promoting intracanal reduction of Enterococcus faecalis. J Endod 2010;2:292-6.

10. Konopka K, Goslinski T. Photodynamic therapy in dentistry. J Dent Res 2007;86:694707.

11. Soukos NS, Chen PS, Morris JT, Ruggiero K, Albernethy AD, Som S, Foschi D et al. Photodynamic therapy for endodontic disinfection. J Endod 2006;32:979-84.

12. Fimple JL, Fontana CR, Foshi F, Ruggiero K, Song X, Pagonis TC et al. Photodynamic treatment of endodontic polymicrobial infection in vitro. J Endod 2008;34:728-34.

13. Garcez AS, Nunez SC, Hamblin MR, Ribeiro MS. Antimicrobial effects of photodynamic therapy on patients with necrotic pulps and periapical lesion. J Endod 2008;34:138-42.

14. Bonsor SJ, Nichol R, Reid TM. Microbiological evaluation of photo-activated disinfection in endodontics (an in vivo study). Br Dent J 2006;200:337-41.

15. Callahan JR. Sulfuric acid for opening root canals. Dent Cosmos 1894;36:957-9.

16. Grossman LI, Meiman B. Solution of pulp tissue by chemical agents. J Am Dent Assoc $1941 ; 28: 223-5$.

17. Koskinen KP, Stenvall H, Uitto VJ. Dissolution of bovine pulp tissue by endodontic irrigants. Scan J Dent Res 1980;88:406-11.

18. Okino LA, Siqueira EL, Santos M, Bombana AC, Figueiredo JAP. Dissolution of pulp tissue by aqueous solution of chlorhexidine digluconate and chlorhexidine digluconate gel. Int Endod J 2004;37:38-41.

19. Rossi-Fedele G, Figueiredo JAP. Use of a bottle warmer to increase $4 \%$ sodium hypochlorite dissolution on bovine pulp. Aust Endod J 2008;34:39-42.

20. Naenni N, Thoma K, Zehnder M. Soft tissue dissolution capacity of currently used and potential irrigants. J Endod 2004;30:785-7.

21. Garcez AS, Núñes SC, Lage-Marques JL, Jorge AOC, Ribeiro MS. Efficiency of $\mathrm{NaOCl}$ and laser-assisted photosensitization on the reduction of Enterococcus faecalis in vitro. Oral Surg Oral Med Oral Pathol Oral Radiol Endod 2006;102:93-8.

22. Eduardo CP, Gouw-Soares S. The use of lasers for endodontic applications in dentistry. Med Laser Appl 2001;16:231-43.

23. Bonsor SJ, Nichol R, Reid TMS, Pearson GJ. An alternative regimen for root canal disinfection. Br Dent J 2006;201:101-5. 